\title{
Meningkatkan Kemampuan Hubungan Interpersonal Melalui Layanan Bimbingan Kelompok Teknik Sosiodrama pada Siswa Kelas IX-1 SMP Negeri 1 Praya
}

\author{
ZEHNI \\ Guru BK SMPN 1 Praya Kabaupaten Lombok Tengah Nusa Tenggara Barat \\ Email:zehni08@yaho.com
}

\begin{abstract}
Abstrak: Hasil studi pendahuluan pada siswa kelas IX-1 SMP Negeri 1 Praya, Lombok Tengah, NTB ditemukan sebanyak 68\% siswa memiliki kemampuan hubungan interpersonal sedang dan rendah. Hasil observasi di kelas juga menunjukkan siswa cenderung pasif pada saat jam pelajaran, pendiam, kurang adanya kerjasama dalam kelompok dan interaksi yang kurang dengan teman-temannya. Guru BK ingin melakukan penelitian tindakan dalam bimbingan dan konseling dengan menggunakan bimbingan kelompok teknik sosiodrama, sebagai upaya dalam meningkatkan kemampuan hubungan interpersonal siswa. Penelitian ini bertujuan untuk mengetahui penerapan bimbingan kelompok dengan teknik sosiodrama untuk meningkatkan kemampuan hubungan interpersonal yang sesuai dengan kebutuhan pada siswa kelas IX-1 SMPN 1 Praya . Desain penelitian tindakan yang digunakan adalah desain PTK Model Kemmis dan Mc Taggrat, Kemmis menggunakan sistem spiral refleksi diri yang dimulai dengan : rencana, tindakan, pengamatan, refleksi dan perencanaan kembali. Berdasarkan hasil penelitian tindakan dalam bimbingan dan konseling dan pembahasan dalam dua kali siklus, dapat disimpulkan bahwa penggunaan layanan bimbingan kelompok dengan teknik sosiodrama dapat meningkatkan kemampuan menjalin hubungan interpersonal pada siswa kelas IX-1 SMP Negeri 1 Praya . Hasil tersebut dapat diketahui dengan adanya peningkatan skor tingkat kemampuan hubungan interpersonal pada siswa antara sebelum dan sesudah penggunaan bimbingan kelompok dengan teknik sosiodrama. Simpulan tersebut didasarkan pada hasil analisis 2 kali post-test dan data observasi yang dilaksanakan selama penelitian dengan dua kali siklus. Hasilnya menunjukkan bahwa dari 8 siswa yang memiliki kemampuan hubungan interpesonal kategori rendah menjadi berkategori tinggi sebanyak 6 siswa dan 2 siswa berkategori sedang, terjadi peningkatan kemampuan hubungan interpersonal pada siswa setelah diberikan perlakuan dengan menggunakan bimbingan kelompok teknik sosiodrama.
\end{abstract}

Kata kunci: Bimbingan Kelompok, Teknik Sosiodrama, Kemampuan Hubungan Interpersonal.

\section{Improving the interpersonal relation skills through sociodrama technic in group guidance service of IX-1 grade students in Junior High School 1 Praya}

\begin{abstract}
In the preliminary study conducted in IX-1 grade students of Junior High School No. 1 Praya, Central Lombok, NTB, it was found that approximately $68 \%$ of the students having low and average interpersonal relation skill. Classroom observations also showed that students tend to be passive during the lesson, quiet, less collaboration in group, and lack of interaction among peers. Guidance and Counselling teachers attemp to conduct a classroom study in guidance and counselling using sociodrama technic group guidance, as an attempt to improve students' interpersonal relation skill. This study is aimed to to find out how the implementation of sociodrama technic group guidance can improve students' interpersonal relation skill based on the needs of IX-1 grade students in junior high school No. 1 Praya. The study design of this classroom action research used Kemmis and Mc Taggrat model, Kemmis used self reflection spiral system, consisted of planning, acting, observating, reflecting, and replanning. Based on the result of this action research in guidance and counselling and discussion in two cycles, it can be conclued that sociodrama technic group guidance can improve IX-1 grade students' interpersonal relation skill in junior high school No. 1 Praya. The result was found from the increasing score of students'
\end{abstract}


interpersonal relation skill before and after the implementation of sociodrama technic group guidance. The conclusion was made based on the analysis result of two times post-test and observation data during the two cycles of this research. The result indicated that 8 students who used to have a low interpersonal relation skill could achieve a higher category of interpersonal relation skill, there were 2 and 6 students having average category of interpersonal relation skill, and there was an increasing trend in interpersonal relation skill among the studets after the sociodrama technic group guidance was implemented.

Key words: Group guidance, sociodrama technic, interpersonal relation skills.

\section{PENDAHULUAN}

Manusia adalah makhluk sosial. Hal ini mengandung arti bahwa manusia tidak dapat hidup sendiri dan selalu menjalin hubungan dengan orang lain, baik dia orang tua, dewasa, anak-anak maupun remaja. Siswa sekolah juga merupakan bagian dari makhluk sosial, sehingga siswa sekolah juga akan terlibat dalam berinteraksi dengan lingkungan sekitarnya. Keperluan menjalin hubungan dengan orang lain dan setiap lingkungan yang dihadapi akan membawa siswa kearah pertumbuhan diri yang lebih maju, sebaliknya individu yang tidak dapat menjalin hubungan dengan baik akan mengalami hambatan dalam pertumbuhan dirinya. Hal ini menunjukkan bahwa hubungan dengan orang lain merupakan aspek yang signifikan dan sangat penting bagi kehidupan.

Jika dikaji lebih dalam hubungan interpersonal merupakan tugas perkembangan yang paling penting bagi seorang siswa SMP dalam menjalankan hubungan sosialnya. Hubungan interpersonal adalah bagaimana individu berinteraksi dan berkomunikasi antara dua orang atau lebih dan dalam kegiatan itu terjadi suatu proses psikologis yang bisa merubah sikap, pendapat atau perilaku orang yang sedang melakukan interaksi tersebut. Jika seorang siswa sudah tidak mampu menjalin hubungan interpersonal, sehingga kemungkinan besar remaja tersebut menjadi individu yang terisolir, serta tidak mampu bergaul dengan lingkungan sosialnya.

Menurut Effendi (1988) mengemukakan

: Hubungan interpersonal yaitu interkomunikasi yang dilakukan oleh seseorang kepada orang lain dalam segala situasi dan didalam semua bidang kehidupan, sehingga menimbulkan rasa puas dan bahagia kepada semua pihak. Hubungan interpersonal yang baik akan membantu dan mendukung individu dalam melakukan hubungan dengan orang lain dalam kaitannya untuk membina kerjasama serta membina persahabatan dengan orang lain.

Berdasarkan hasil pengamatan langsung yang dilakukan selama melaksanakan layanan BK secara klasikal di kelas pada bulan Agustus sampai dengan Oktober, bahwa siswa di kelas IX-1 menunjukkan kurangnya interaksi antara siswa satu dengan yang lainnya, cenderung diam dan malu-malu, siswa terlihat jarang berbicara dengan teman satu kelas, merasa takut untuk menyatakan pendapat kepada teman yang lain. Berdasarkan wawancara dengan beberapa siswa, menyatakan bahwa rata-rata siswa dari kelas IX-1 teridentifikasi memiliki hubungan interpersonal yang rendah. Perilaku yang nampak di dalam kelas adalah siswa yang cenderung pasif pada saat jam pelajaran, pendiam, kurang adanya kerjasama dalam kelompok dan interaksi yang kurang dengan teman-temannya. Kesulitan yang dialami oleh siswa pada umumnya disebabkan oleh beberapa faktor penyebab diantaranya lingkungan, keluarga dan diri sendiri seperti kurangnya komunikasi, perasaan minder dan malu-malu.

Siswa tersebut masih kurang memiliki kemampuan dalam melakukan hubungan dengan orang lain. Tentu saja hal tersebut akan mengakibatkan komunikasi serta perkembangan kehidupan sosial siswa di lingkungan sekolah juga kurang. Menjalin hubungan yang baik dan efektif sangat penting bagi siswa dalam upaya meningkatkan kemampuan hubungan 
interpersonal dengan orang lain. Untuk meningkatkan hubungan interpersonal siswa, konselor telah memberikan layanan informasi tentang pergaulan dengan teman sebaya serta pemberian nasehat kepada siswa. Namun nasehat tersebut belum dapat dilakukan siswa secara maksimal karena pada dasarnya siswa tidak benar-benar melaksanakan nasehat tersebut. Seharusnya bukan hanya nasehat yang diberikan kepada siswa, tetapi lebih pada cara-cara untuk meningkatkan hubungan interpersonal siswa.

Kemampuan menjalin hubungan interpersonal yang rendah pada siswa harus segera diatasi agar siswa mampu mengembangkan hubungan dengan sesama ke arah yang memuaskan dan membahagiakan. Tidak dapat dipungkiri bahwa prestasi belajar siswa merupakan salah satu hasil dari suatu proses menjalin hubungan interpersonal siswa dengan semua warga sekolah, baik itu teman, guru, kepala sekolah, dan petugas tata usaha. Apabila siswa tidak memiliki kemampuan menjalin hubungan interpersonal yang baik, siswa akan sulit menjalin hubungan interpersonal yang baik dengan semua warga sekolah. Hal ini tentu saja akan mempengaruhi prestasi belajar siswa, sehingga siswa tidak mencapai prestasi belajar yang optimal sesuai dengan standar kompetensi yang telah ditentukan. Bimbingan dan konseling di sekolah merupakan fasilitas yang diberikan melalui konselor sekolah dalam rangka membantu siswa dalam proses mengembangkan dirinya.

Untuk menyikapi masalah kurangnya kemampuan hubungan interpersonal siswa kelas IX-1 di SMP Negeri 1 Praya, maka bimbingan dan konseling menawarkan layanan bimbingan kelompok untuk mengatasi masalah yang berkaitan dengan hubungan interpersonal dengan menggunakan teknik sosiodrama. Menurut Winkel (2006 : 545) bimbingan kelompok adalah layanan bimbingan yang diberikan kepada lebih dari satu orang pada waktu yang bersamaan. Bimbingan dan konseling bertujuan untuk membantu siswa mencapai perkembangan yang optimal melalui berbagai bentuk layanan baik yang bersifat individu maupun kelompok (dalam Nursalim, 2005 : 127).

$$
\text { Ahmad dan Supriono }
$$

menjelaskan bahwa sosiodrama adalah suatu cara dalam bimbingan yang memberikan kesempatan pada murid-murid untuk mendramatisasikan sikap, tingkah laku, atau penghayatan seseorang seperti yang dilakukan dalam hubungan sosial sehari-hari dimasyarakat. Sedangkan menurut Romlah (2006:104) mengemukakan bahwa sosiodrama adalah permainan peran yang ditujukan untuk memecahkan masalah sosial yang timbul dalam hubungan antar manusia.

Dalam teknik sosiodrama siswa bukan hanya dituntut untuk memainkan drama dengan baik, tetapi juga dituntut untuk membuka diri terhadap orang lain melalui komunikasi dan interaksi, serta memahami pesan pribadi dan pesan orang lain. Dengan mendramatisasikan suatu persoalan dapat membantu siswa untuk memahami perannya sendiri dan peran yang dimainkan orang lain, sambil mengerti perasaan, sikap, dan nilai yang mendasarinya. Melalui sosiodrama dalam bimbingan kelompok diharapkan siswa dapat memperoleh wawasan tentang sikap, nilai dan persepsinya, mengembangkan keterampilan dan sikap dalam memecahkan masalah yang dihadapi, mengeksplorasi inti permasalahan yang diperankan melalui berbagai cara. Sehingga siswa dapat mengeksplorasi perasaan dan berinteraksi antar anggota kelompok sehingga akan timbul sikap saling percaya untuk mengungkapkan apa yang sedang dialaminya.

Berdasarkan pemaparan latar belakang diatas dan hasil wawancara dengan beberapa siswa di SMP Negeri 1 Praya, dimana terdapat siswa kelas IX-1 yang memiliki kemampuan hubungan interpersonal rendah, sehingga muncul keinginan untuk melakukan penelitian tindakan dalam bimbingan dan konseling dengan menggunakan bimbingan kelompok teknik sosiodrama untuk meningkatkan kemampuan hubungan interpersonal siswa. Penelitian yang peneliti lakukan berjudul "Meningkatkan kemampuan hubungan interpersonal melalui layanan 
bimbingan kelompok teknik sosiodrama pada siswa kelas IX-1 SMP Negeri 1 Praya”.

\section{METODE}

Dalam penelitian tindakan bimbingan dan konseling ini desain penelitian tindakan yang digunakan adalah desain PTK Model Kemmis dan Mc Taggrat. Dalam perencanaannya, Kemmis menggunakan sistem spiral refleksi diri yang dimulai dengan : rencana, tindakan, pengamatan, refleksi dan perencanaan kembali (Arikunto, 2008:20).

Penelitian tindakan kelas ini dilakukan dalam bentuk siklus, siklus yang dirancang dalam penelitian ini sebanyak 2 siklus dan dalam tiap siklus terdiri dari 1 atau 2 pertemuan sesuai dengan kebutuhan yang sewaktu-waktu bisa berubah. Masing-masing siklus memiliki 4 tahapan yaitu : melakukan perencanaan, melakukan tindakan, melakukan pengamatan, serta melakukan refleksi pada hasil. Setelah siklus 1 dilakukan selanjutnya mempersiapkan perencanaan ulang untuk siklus 2 yang didasarkan pada hasil pengamatan pada siklus 1 .

Berikut bagan pelaksanaan penelitian pada masing-masing siklus sesuai dengan desain PTK Model Kemmis \& Mc Taggart.

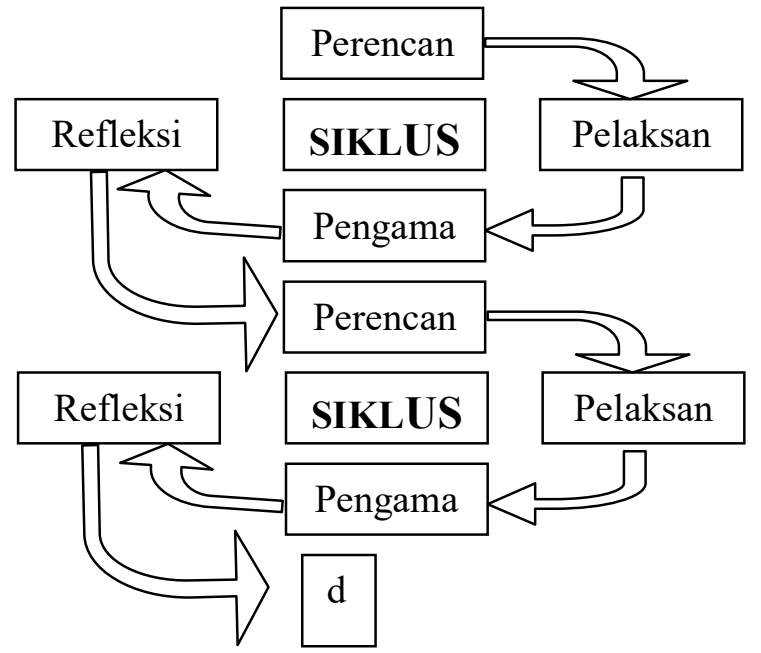

\section{Gambar 1. Model Penelitian Tindakan} Kelas Model Kemmis \& Mc Taggart

Subyek penelitian ini adalah siswa kelas IX-1 di SMP Negeri 1 Praya yang memiliki skor terendah dari hasil mengisi angket tentang hubungan interpersonal siswa. Penelitian tindakan kelas ini dilakukan dalam layanan bimbingan kelompok teknik sosiodrama dan penelitian ini dilakukan pada semester ganjil tahun ajaran 2017-2018.

Data merupakan kumpulan informasi yang diperlukan dalam penelitian ini, data tersebut meliputi: (a) data aktifitas atau keaktifan siswa ketika mengikuti layanan informasi, (b) data berupa pendapat atau respon siswa, guru terhadap metode penyampaian layanan.

Sumber data dari penelitian ini adalah peneliti, dokumen, guru dan siswa.

Untuk memperoleh data yang akurat serta menunjang terlaksananya penelitian ini maka diperlukan instrumen penelitian diantaranya adalah : Rencana Pelaksanaan Bimbingan dan Konseling (RPBK), Lembar observasi, Angket.

Teknik pengumpulan data pada penelitian ini antara lain : Angket, Observasi, Wawancara. Menurut Arikunto dkk, (2008:131), pada penelitian tindakan kelas dapat digunakan dua jenis analisis data yaitu : 1. Data kuantitatif (nilai hasil observasi tingkat keaktifan siswa ketika mengikuti layanan informasi) yang dapat dianalisis secara deskriptif. Dalam hal penelitian menggunakan analisis statistik deskriptif. Misalnya mencari nilai rerata, presentase keberhasilan belajar, dan lain-lain. 2. Data kualitatif yaitu data yang berupa informasi berbentuk kalimat yang memberikan gambaran tentang ekspresi siswa tentang tingkat pemahaman terhadap suatu mata pelajaran (kognitif), pandangan atau sikap siswa terhadap metode pelajaran yang baru (afektif), aktifitas siswa mengikuti pelajaran, perhatian, antusias dalam belajar, kepercayaaan diri, motivasi belajar, dan sejenisnya dapat dianalisis dengan data kualitatif.

\section{HASIL DAN PEMBAHASAN}

Sebelum melaksanakan penelitian tindakan peneliti menyebarkan angket yang digunakan untuk mengetahui tingkat awal kemampuan hubungan interpersonal siswa. Dari hasil angket yang dikerjakan oleh siswa, maka dapat diketahui skor masing-masing siswa yang selanjutnya dilakukan penentuan skor untuk melihat kategori, yaitu kemampuan hubungan interpersonal kategori 
tinggi, sedang dan rendah. Skor tersebut diperoleh dengan menggunakan standart deviasi. Dari hasil skor pre-test kemampuan hubungan interpersonal siswa kelas IX-1, diperoleh 8 siswa dengan kemampuan hubungan interpersonal rendah. 8 siswa tersebut nantinya akan diberikan perlakuan berupa bimbingan kelompok dengan teknik sosiodrama untuk meningkatkan kemampuan hubungan interpersonal.

Penelitian tindakan kelas ini dilakukan dalam bentuk siklus, siklus yang dirancang dalam penelitian ini sebanyak 2 siklus dan dalam tiap siklus terdiri dari 1 atau 2 pertemuan sesuai dengan kebutuhan yang sewaktu-waktu bisa berubah. Masing-masing siklus memiliki 4 tahapan yaitu : melakukan perencanaan, menentukan tindakan, melakukan pengamatan, serta melakukan refleksi pada hasil. Setelah siklus I dilakukan selanjutnya mempersiapkan perencanaan ulang untuk siklus II yang didasarkan pada hasil pengamatan pada siklus I.

Aktivitas konselor berdasarkan hasil penelitian yang telah dilaksanakan pada siklus I dan II dapat dipresentasikan melalui gambar berikut:

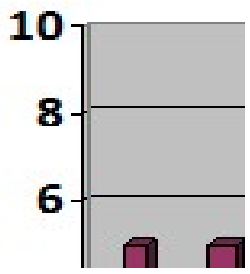

Gambar 2 : Aktivitas Konselor dalam Bimbingan Kelompok Teknik Sosiodrama Siklus I dan Siklus II (Observer 1 \& 2)

Dari tabel dan diagram di atas, dapat dilihat bahwa kemampuan konselor dalam melaksanakan bimbingan kelompok teknik sosiodrama, mengalami peningkatan dari siklus I hingga siklus II. Pada proses bimbingan kelompok siklus I, konselor sudah mencapai target penyampaian proses bimbingan kelompok akan tetapi belum maksimal sesuai dengan apa yang telah ditentukan, walaupun demikian konselor menyampaikan proses pembelajaran dengan baik dibuktikan pencapaian nilai yang meningkat pada siklus II dan tingkat keberhasilan dalam penyampaikan proses bimbingan kelompok teknik sosiodrama adalah sebesar $80 \%$.

Data hasil pengamatan aktifitas siswa dari siklus I dan siklus II sebagai berikut:

Tabel 1. Aktifitas siswa siklus I dan II

\begin{tabular}{|l|l|l|l|}
\hline No. & Siklus & Jumlah & Persentase \\
\hline 1. & I & 230 & $71,88 \%$ \\
\hline 2. & II & 289 & $90,31 \%$ \\
\hline
\end{tabular}

Dari tabel di atas dapat diketahui bahwa bimbingan kelompok teknik sosiodrama dapat dipergunakan untuk meningkatkan kemampuan hubungan interpersonal pada siswa kelas IX-1 SMP Negeri 1 Praya, terdapat penin gkatkan dari siklus I ke siklus II secara bertahap sesuai dengan aspek-aspek yang terdapat dalam lembar observasi siswa untuk mendukung peningkatan kemampuan siswa. Diketahui bahwa pada siklus pertama persentase aktifitas siswa sebesar $71,88 \%$ dan terjadi peningkatan pada siklus II menjadi 90,31 \% dan dapat diketahui bahwa peningkatan kemampuan hubungan interpersonal siswa secara bertahap meningkatkan $18,43 \%$.

Pembahasan Hasil Pre-test, Post-Test siklus I, dan Post-Test Siklus II dalam penelitian ini disajikan dalam Tabel 2, sebagai berikut :

\section{Tabel 2. Hasil Pre-test, Post-Test siklus I,} dan Post-Test Siklus II

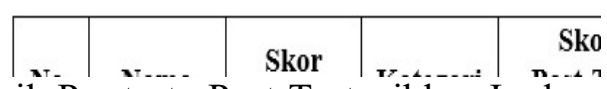

Hasil Pre-test, Post-Test siklus I, dan Post-Test Siklus II dalam penelitian ini Jika digambarkan dengan gambar, disajikan dalam Gambar 3, sebagai berikut : 


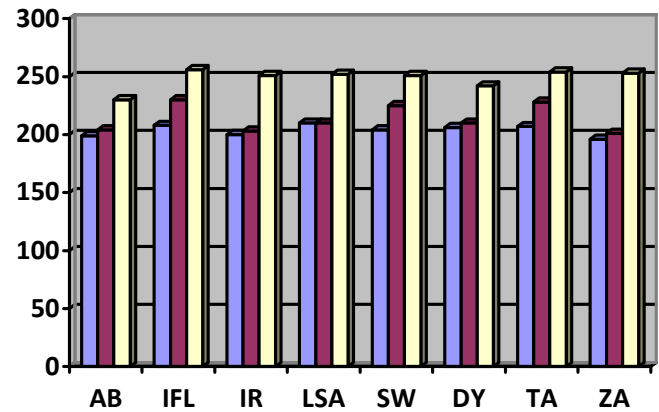

Gambar 3 : Hasil Pre-Test, Post-Test 1 dan Post-Test 2 Bimbingan Kelompok Teknik Sosiodrama untuk Meningkatkan Kemampuan Komunikasi Interpersonal

Berdasarkan gambar diatas dapat dilihat adanya perbedaan. Hasil pre-tst lebih rendah daripada hasil post-test 1 dan 2 . Hal tersebut menunjukkan bahwa ada peningkatan skor tingkat kemampuan hubungan interpersonal siswa kelas IX-1 SMP Negeri 1 Praya antara sebelum dan sesudah diberikan perlakuan berupa bimbingan kelompok dengan teknik sosiodrama.

\section{SIMPULAN}

Kemampuan hubungan interpersonal yang baik tentunya akan memberikan dampak positif bagi siswa. Siswa dengan kemampuan hubungan interpersonal yang baik akan mampu menjalin persahabatan, mampu bekerja sama dengan teman-temannya, mampu mengungkapkan pikiran dan perasaannya. Dalam penelitian tindakan dalam bimbingan dan konseling ini dan pembahasan dalam dua kali siklus, dapat disimpulkan bahwa penggunaan layanan bimbingan kelompok dengan teknik sosiodrama dapat meningkatkan kemampuan menjalin hubungan interpersonal pada siswa kelas IX-1 SMP Negeri 1 Praya . Hasil tersebut dapat diketahui dengan adanya peningkatan skor tingkat kemampuan hubungan interpersonal pada siswa antara sebelum dan sesudah penggunaan bimbingan kelompok dengan teknik sosiodrama. Simpulan tersebut didasarkan pada hasil analisis 2 kali post-test dan data observasi yang dilaksanakan selama penelitian dengan dua kali siklus. Hasilnya menunjukkan bahwa terjadi peningkatan kemampuan hubungan interpersonal pada siswa setelah diberikan perlakuan dengan menggunakan bimbingan kelompok teknik sosiodrama. Dengan demikian hipotesis penelitian yang berbunyi "Kemampuan menjalin hubungan interpersonal dapat meningkat melalui bimbingan kelompok teknik sosiodrama pada siswa di kelas IX-1 SMP Negeri 1 Praya " dapat diterima.

\section{DAFTAR RUJUKAN}

Ahmad dan Supriono. 2004. Psikologi Belajar. Jakarta: Rineka Cipta.

Alisyahbana, I.B. 2014. Penerapan Teknik Sosiodrama untuk Meningkatkan Komunikasi Interpersonal pada Kelas VII F di SMPN 1 Kemlagi Mojokerto. Skripsi tidak diterbitkan. Surabaya: Fakultas Ilmu Pendidikan, Universitas Negeri Surabaya.

Arikunto, dkk. 2008. Prosedur Penelitian. Jakarta: PT. Rineka Cipta.

Devito, J.A. 2001. Komunikasi Antarmanusia, Terjemahan oleh Agus Maulana. Tangerang: Karisma Publishing Grup.

Effendy, O.U. 1988. Hubungan Insani. Bandung: CV. Remadja Karya.

Hartinah, S. 2009. Konsep Dasar Bimbingan Kelompok. Bandung : P.T Refika Aditama.

Kemmis, S. And Mc Taggart R. 1999. The Action Research Planner Third Edition. Deakin University.

Mulyana, D. 2001. Ilmu Komunikasi : Suatu Pengantar. Bandung: P.T Remaja Rosdakarya.

Nursalim, dkk. 2002. Layanan Bimbingan Dan Konseling. Surabaya: Unesa University Press.

Rakhmat, J. 2005. Psikologi Komunikasi. Bandung: P.T Remaja Rosdakarya Offset.

Roestiyah, N.K. 2001. Strategi Belajar Mengajar. Jakarta: Asdi Mahasatya.

Romlah, T. 2006. Teori dan Praktek Bimbingan Kelompok. Malang: Universitas Negeri Malang.

Sears, dkk. 1985. Psikologi Sosial Edisi Kelima. Jakarta: P.T Erlangga. 
Supratiknya, A.A. 1995. Komunikasi Antarpribadi. Yogyakarta: P.T Kanisius.

Suryani, L.E. 2013. Penerapan Teknik Sosiodrama untuk Meningkatkan Komunikasi yang Beretika pada Siswa di SMA Negeri 1 Gondang. Skripsi tidak diterbitkan. Surabaya: Fakultas Ilmu Pendidikan, Universitas Negeri Surabaya.

Winkel, W.S. 2006. Bimbingan dan Konseling di Institusi Pendidikan. Yogyakarta: Media Abadi. 